\title{
Polyether Hexadentate Schiff Base Ligand with Trivalent Chromium, Iron, Cobalt Ions
}

\author{
Farah M. Ibrahim \\ Department of Chemistry, College of Science, Al-Nahrain University, Baghdad-Iraq. \\ Corresponding author: farahtaha2016@gmail.com.
}

\begin{abstract}
Williamson etherification method used to prepared ether compound from salicylaldehyde with 1,3-dibromopropane and potassium carbonate as base, this compound used with 2-amino-4chlorophenol to prepare polyether hexadentate Schiff base ligand (HSL) by the 1:2 molar condensations. $\mathrm{Cr}^{3+}, \mathrm{Fe}^{3+}, \mathrm{Co}^{3+}$ ions were reacted with $\mathrm{HSL}$ and characterized by ${ }^{1} \mathrm{H} \mathrm{NMR}$ and ${ }^{13} \mathrm{CNMR}$ technique, infrared, electronic spectra, elemental analysis, thermal analysis, conductivity and magnetic susceptibility measurements, from results the metal ion was bonded to the HSL through the phenol oxygen, imine nitrogen and ether oxygen atoms to suggest octahedral configurations. The biological activity of HSL with its complexes have been studied.
\end{abstract}

[DOI: 10.22401/JNUS.20.4.01]

Keywords: Hexadentate ligand, Schiff base, Williamson etherification, metal ion complexes.

\section{Introduction}

The Williamson ether synthesis is a method of preparation of ethers using a base, it is a nucleophilic substitution $\left(\mathrm{SN}_{2}\right)$ reaction starting from aromatic aldehydes with bromoalkanes [1]. Schiff bases which have hetero donor atoms used in different fields such as analytical chemistry, coordination chemistry, organic synthesis, industrial and biological and known as heteropolydentate ligands [28],these ligands combine with polyether ligands contain ethylene bridge, separated by oxygen atom have received wide attention because of show ability to form stable complexes with transition metal ions [9-14]. A hexadentate dibasic $\mathrm{N}_{2} \mathrm{~S}_{2} \mathrm{O}_{2}$ Schiff base derivates from 3-formylsalicylic acid was prepared by the condensation reaction and then reacted with metal (II, III) salts to form different metal complex configurations [15]. Hexadentate Schiff base of 2-hydroxybenzaldehyde with transition ions were prepared and investigated, these transition complexes used as catalysts in the allylic and benzylic reaction and showed great catalytic activity [16]. A novel Ln(III) polyether hexadentate di-Schiff base complexes $\left(\mathrm{N}_{4} \mathrm{O}_{2}\right)$ were characterized by spectroscopic and thermogravimetric techniques [17]. A hexadentate Schiff base ligand have ether oxygens were coordinate to the $\mathrm{Fe}(\mathrm{III}), \mathrm{Co}(\mathrm{III})$ and $\mathrm{Ni}$ (II) ions and characterized by analytical, spectral and magnetic methods [18]. New polyether ligands with Schiff base were synthesized and characterized by nuclear magnetic reasonance, infrared and electronic analysis, the thermo gravimetric decomposition was shown stable polyether ligands with Schiff base against thermooxidative analyses [19].

In this work polyether hexadentate Schiff base ligand with trivalent transition metal ions are synthesized and characterized by different spectral technique to suggest the octahedral structure, the antibacterial activity of HSL with CrHSL, FeHSL, CoHSL complexes are measured.

\section{Experimental Work \\ 2.1. Instrumentation}

Infrared spectra were measured using FTIR 8300 Shimadzu. The UV-Visible spectra were measured by Shimadzu UV-Vis 160A spectrophotometer. The metal ion percent of the prepared complexes were measured by Shimadzu $680 \mathrm{cc}$-flame. ${ }^{1} \mathrm{H}$ and ${ }^{13} \mathrm{C}$ nuclear magnetic resonance spectra were recorded on a jeol $400 \mathrm{MHz}$ spectrometer in DMSO- $\mathrm{d}_{6}$ as a solvent and tetramethylsilane (TMS) as internal reference. CHNS-O analysis was carried out on EURO EA elemental analyzer. Thermal analyses (TG-DTG) were gained on a LINSEIS (STA PT-1000). Magnetic susceptibility of the complexes were obtained using magnetic susceptibility balance Johnson Mattey catalytic system at room temperature 
and molar conductivity measurements were carried out at room temperature using corning conductivity meter 220. Melting points of ligand and their complexes were measured by Gallenkamp M.F.B. 600.01 apparatus.

\subsection{Preparation of polyether compound:}

1,3-dibromopropane $\quad(2.02 \mathrm{~g}, 1 \mathrm{~mol}) \quad$ was added to salicylaldehyde $(2.44 \mathrm{~g}, 2 \mathrm{~mol})$ and $\mathrm{K}_{2} \mathrm{CO}_{3}(2.76 \mathrm{~g}, 2 \mathrm{~mol})$ in ethanol $(25 \mathrm{ml})$ as a solvent then the mixture was refluxed for $48 \mathrm{~h}$ and left to cool at room temperature, filtered off, diluted with water $(25 \mathrm{ml})$ and extracted by ether $(2 \times 20 \mathrm{ml})$, the combined organic layers were washed with $5 \% \mathrm{NaOH}(20 \mathrm{ml})$, $5 \% \mathrm{HCl}(20 \mathrm{ml})$, water $(20 \mathrm{ml})$ after that dried with anhydrous $\mathrm{Na}_{2} \mathrm{SO}_{4}$, filtered, left to dryness to give ether compound(2.1g) [20].

\subsection{Preparation of polyether hexadentate}

Schiff base ligand (HSL):

Absolute ethanol solution $(10 \mathrm{ml})$ of 2-amino-4-chloroophenol $(2.87 \mathrm{~g}, 2 \mathrm{~mol})$ was mixed with absolute ethanol solution $(10 \mathrm{ml})$ of ether compound $(2.84 \mathrm{~g}, 1 \mathrm{~mol})$. The resulting mixture was refluxed on a water bath for $8 \mathrm{~h}$, then left to cool to room temperature; yellow product was precipitated and speared by filtration, then washed with cold ethanol, dried in an oven at $50^{\circ} \mathrm{C}(4.8 \mathrm{~g})$.

\subsection{Preparation of the trivalent metal complexes:}

The complexes were prepared by mixing hot ethanolic solution of metal salts $\left(\mathrm{CrCl}_{3} \cdot 6 \mathrm{H}_{2} \mathrm{O}, \mathrm{CoCl}_{3} \cdot 6 \mathrm{H}_{2} \mathrm{O}, \mathrm{FeCl}_{3} \cdot 9 \mathrm{H}_{2} \mathrm{O}\right)$ with hot ethanolic solution of HSL 1:1 (metal: ligand) mole ratio and refluxed for 6 hours. A colored precipitate was formed, filtered and washed with hot ethanol then dried in oven at $50^{\circ} \mathrm{C}$.

\section{Results and Discussion}

Characterization results of HSL with its complexes set out at Table (1).

Table (1)

Some characterization data of HSL and metal complexes.

\begin{tabular}{|c|c|c|c|c|c|c|c|c|}
\hline \multirow{2}{*}{ Compound } & \multirow{2}{*}{$\begin{array}{c}\text { Conductivity, } \\
\text { DMFsolvent } \\
\mu \mathrm{s} / \mathrm{cm}\end{array}$} & \multirow{2}{*}{$\begin{array}{l}\text { Melting } \\
\text { Point, }{ }^{\circ} \mathrm{C} \\
\text { colour }\end{array}$} & \multicolumn{5}{|c|}{$\begin{array}{c}\text { Found \% } \\
\text { (Calculate)\% }\end{array}$} & \multirow{2}{*}{$\begin{array}{l}\text { Suggested } \\
\text { formula }\end{array}$} \\
\hline & & & $\mathbf{C}$ & +H & $\mathbf{O}$ & $\mathbf{N}$ & Metal & \\
\hline HSL & - & $\begin{array}{l}244-246 \\
\text { Yellow }\end{array}$ & $\begin{array}{c}65.55 \\
(65.06)\end{array}$ & $\begin{array}{c}4.22 \\
(4.49)\end{array}$ & $\begin{array}{c}11.11 \\
(11.96)\end{array}$ & $\begin{array}{c}2.20 \\
(5.23)\end{array}$ & - & $\mathrm{C}_{29} \mathrm{H}_{24} \mathrm{~N}_{2} \mathrm{O}_{4} \mathrm{Cl}_{2}$ \\
\hline CrHSL & 69.4 & $\begin{array}{c}250-252 \\
\text { Dark green }\end{array}$ & $\begin{array}{c}54.10 \\
(54.52)\end{array}$ & $\begin{array}{c}3.55 \\
(3.76)\end{array}$ & $\begin{array}{c}12.15 \\
(12.53)\end{array}$ & $\begin{array}{c}4.33 \\
(4.39)\end{array}$ & $\begin{array}{c}8.19 \\
(8.14)\end{array}$ & {$\left[\mathrm{Cr} \mathrm{C}_{29} \mathrm{H}_{22} \mathrm{~N}_{2} \mathrm{O}_{4} \mathrm{Cl}_{2}\right] \mathrm{Cl} . \mathrm{H}_{2} \mathrm{O}$} \\
\hline FeHSL & 75.5 & $\begin{array}{c}255-257 \\
\text { Pale yellow }\end{array}$ & $\begin{array}{c}54.11 \\
(54.19)\end{array}$ & $\begin{array}{c}3.45 \\
(3.74)\end{array}$ & $\begin{array}{c}12.99 \\
(12.46)\end{array}$ & $\begin{array}{c}4.55 \\
(4.36)\end{array}$ & $\begin{array}{c}8.88 \\
(8.69)\end{array}$ & {$\left[\mathrm{Fe} \mathrm{C}{ }_{29} \mathrm{H}_{22} \mathrm{~N}_{2} \mathrm{O}_{4} \mathrm{Cl}_{2}\right] \mathrm{Cl} \cdot \mathrm{H}_{2} \mathrm{O}$} \\
\hline CoHSL & 85.7. & $\begin{array}{c}280-282 \\
\text { Brown }\end{array}$ & $\begin{array}{c}53.00 \\
(53.93)\end{array}$ & $\begin{array}{c}3.91 \\
(3.72)\end{array}$ & $\begin{array}{c}12.45 \\
(12.39)\end{array}$ & $\begin{array}{c}4.35 \\
(4.34)\end{array}$ & $\begin{array}{c}9.10 \\
(9.13)\end{array}$ & {$\left[\mathrm{Co} \mathrm{C}_{29} \mathrm{H}_{22} \mathrm{~N}_{2} \mathrm{O}_{4} \mathrm{Cl}_{2}\right] \mathrm{Cl} \cdot \mathrm{H}_{2} \mathrm{O}$} \\
\hline
\end{tabular}

\subsection{Thermal analysis of metal complexes}

The mass lose results that calculated and observed of complexes in the temperature ranges $\left(30-900{ }^{\circ} \mathrm{C}\right)$ using helium as inert gas were listed in Table (2), The first step of lose confirm the $\mathrm{H}_{2} \mathrm{O}$ molecule in the outer of coordination sphere was presence, the final step of mass lose gave oxide of metal after another steps of thermal decomposition [21]. 
Table (2)

Thermal decomposition of HSL complexes.

\begin{tabular}{|c|c|c|c|c|c|}
\hline \multirow{2}{*}{ Complex formula } & \multirow{2}{*}{$\begin{array}{c}\text { Temperature } \\
\text { range, }{ }^{\circ} \mathrm{C}\end{array}$} & \multicolumn{2}{|c|}{ Weight loss\% } & \multirow{2}{*}{$\begin{array}{c}\begin{array}{c}\text { Decomposition } \\
\text { complex }\end{array} \\
\end{array}$} & \multirow{2}{*}{$\begin{array}{c}\text { Liberate } \\
\text { moiety }\end{array}$} \\
\hline & & Calculate & Found & & \\
\hline \multirow[t]{4}{*}{$\overline{\mathrm{Cr}\left[\mathrm{C}_{29} \mathrm{H}_{24} \mathrm{~N}_{2} \mathrm{O}_{5} \mathrm{Cl}_{3}\right]}$} & $10100-150$ & 25.67 & 24.3 & $\overline{\mathrm{Cr}}\left[\mathrm{C}_{23} \mathrm{H}_{19} \mathrm{~N}_{2} \mathrm{O}_{4} \mathrm{Cl}\right]$ & $\begin{array}{l}-\mathrm{Cl}_{2} \\
-\mathrm{C}_{6} \mathrm{H}_{3} \\
-\mathrm{H}_{2} \mathrm{O}\end{array}$ \\
\hline & $150-288$ & 11.75 & 10.6 & $\mathrm{Cr}\left[\mathrm{C}_{17} \mathrm{H}_{16} \mathrm{~N}_{2} \mathrm{O}_{4} \mathrm{Cl}\right]$ & $-\mathrm{C}_{6} \mathrm{H}_{3}$ \\
\hline & $288-400$ & 10.68 & 10.7 & $\mathrm{Cr}\left[\mathrm{C}_{15} \mathrm{O}_{4} \mathrm{Cl}\right]$ & $\begin{array}{l}-2(\mathrm{CNH}) \\
-14 \mathrm{H} \\
\end{array}$ \\
\hline & 4400-800 & 22.45 & 21.19 & $\mathrm{Cr}\left[\mathrm{C}_{6} \mathrm{O}_{4}\right]$ & $\begin{array}{l}-3 C \\
-C l \\
-6 C \\
\end{array}$ \\
\hline \multirow[t]{4}{*}{$\mathrm{Fe}\left[\mathrm{C}_{29} \mathrm{H}_{24} \mathrm{~N}_{2} \mathrm{O}_{5} \mathrm{Cl}_{3}\right]$} & $120-190$ & 22.02 & 22.8 & $\mathrm{Fe}\left[\mathrm{C}_{23} \mathrm{H}_{6} \mathrm{~N}_{2} \mathrm{O}_{4} \mathrm{Cl}_{2}\right]$ & $\begin{array}{l}-\mathrm{Cl} \\
-\mathrm{C}_{6} \mathrm{H}_{16} \\
-\mathrm{H}_{2} \mathrm{O}\end{array}$ \\
\hline & $233-300$ & 6.45 & 6.20 & $\mathrm{Fe}\left[\mathrm{C}_{23} \mathrm{~N}_{2} \mathrm{O}_{4} \mathrm{Cl}\right]$ & $\begin{array}{l}-\mathrm{Cl} \\
-6 \mathrm{H} \\
\end{array}$ \\
\hline & $315-500$ & 36.04 & 35.90 & $\mathrm{Fe}\left[\mathrm{C}_{9} \mathrm{O}_{4}\right]$ & $\begin{array}{l}-\mathrm{C}_{7} \mathrm{NCl} \\
-\mathrm{C}_{7} \mathrm{~N} \\
\end{array}$ \\
\hline & 533-700 & 16.81 & 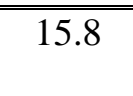 & $\overline{\mathrm{Fe}}\left[\mathrm{O}_{4}\right]$ & $\begin{array}{l}-3 C \\
-6 C\end{array}$ \\
\hline \multirow[t]{4}{*}{$\overline{\mathrm{Co}\left[\mathrm{C}_{29} \mathrm{H}_{24} \mathrm{~N}_{2} \mathrm{O}_{5} \mathrm{Cl}_{3}\right]}$} & "100-160 & 19.9 & 17.79 & $\overline{\mathrm{C}} \mathrm{Co}\left[\mathrm{C}_{23} \mathrm{H}_{19} \mathrm{~N}_{2} \mathrm{O}_{4} \mathrm{Cl}_{2}\right]$ & $\begin{array}{l}-\mathrm{C}_{6} \mathrm{H}_{3} \mathrm{Cl} \\
-\mathrm{H}_{2} \mathrm{O}\end{array}$ \\
\hline & $160-280$ & 6.51 & 6.00 & $\mathrm{Co}\left[\mathrm{C}_{20} \mathrm{H}_{13} \mathrm{~N}_{2} \mathrm{O}_{4} \mathrm{Cl}_{2}\right]$ & $-3\left(\mathrm{CH}_{2}\right)$ \\
\hline & $280-410$ & 37.28 & 34.79 & $2 \mathrm{Co}\left[\mathrm{C}_{6} \mathrm{H}_{4} \mathrm{O}_{4} \mathrm{Cl}\right]$ & $\begin{array}{l}-\mathrm{C}_{6} \mathrm{H}_{3} \mathrm{Cl} \\
-2(\mathrm{CHN}) \\
-\mathrm{C}_{6} \mathrm{H}_{4}\end{array}$ \\
\hline & "410-800 & 17.27 & 17.50 & $\overline{\mathrm{CO}}\left[\mathrm{O}_{4}\right]$ & $\begin{array}{l}-\mathrm{C}_{6} \mathrm{H}_{4} \\
-\mathrm{Cl} \\
\end{array}$ \\
\hline
\end{tabular}

\subsection{IR and NMR spectrum}

Infrared spectrum of the HSL displays band at $1636 \mathrm{~cm}^{-1}$ indicating to $v \mathrm{C}=\mathrm{N}$, this band shift to lower wave number suggested the coordinating of carbon nitrogen double bond to the metal ion in the infrared spectra of the complexes [14]. v(C-O-C) appear around $1210 \mathrm{~cm}^{-1}$ in a HSL, in the spectra of the complexes these stretching frequencies were observed around (1120-1151) $\mathrm{cm}^{-1}$ indicating to coordination of ether oxygen atom. $v \mathrm{O}-\mathrm{H}$ band appear at $3500 \mathrm{~cm}^{-1}$ in the HSL, the disappearance of absorption bands in the complexes spectra confirms the coordination of phenolic oxygen with trivalent transition ion [21]. New bands in the (460-489) $\mathrm{cm}^{-1}$ and (525-569) $\mathrm{cm}^{-1}$ regions, supports the bond of $v \mathrm{M}-\mathrm{O}$ and $v \mathrm{M}-\mathrm{N}$, respectively, these frequencies shown in Table (3).
${ }^{1}$ HNMR spectral study for HSL, Fig.(1): $\delta(2.5,3.4) \mathrm{ppm}$ for methyl protons in different positions $\mathrm{CH}_{2}-\mathrm{CH}_{2}$ and $\mathrm{CH}_{2}-\mathrm{O}, \delta 5.46 \mathrm{ppm}$ (broad s, 2H, OH), signals in the region (6.86-7.62) due to aromatic protons, 8.96 characteristic resonance due to imine proton $(\mathrm{s}, 2 \mathrm{H}, \mathrm{N}=\mathrm{CH})$. The ${ }^{1} \mathrm{HNMR}$ of complexes reveals the absence of $\mathrm{O}-\mathrm{H}$ group due to the coordination. $\mathrm{N}=\mathrm{CH}$ signals of complexes shift to $9.10 \mathrm{ppm}$ due to the coordination and also $\mathrm{CH}_{2}-\mathrm{O}$ signals shift to3.10 ppm indicating to coordination to metal ions through oxygen ether. ${ }^{13} \mathrm{C}$ NMR of HSL, Fig.(2): $\mathrm{C}-\mathrm{OH}$ appear at $\delta(160.1) \mathrm{ppm}$ shift to (161.0)ppm in complexes spectra, signals in the region (115-150) ppm for aromatic carbons rings, (162.10) $\mathrm{ppm}$ refer to the $\mathrm{CH}=\mathrm{N}$ shift to (162.99) $\mathrm{ppm}$ in complexes spectra, $\mathrm{CH}_{2}-\mathrm{CH}_{2}$ (40.45) ppm, $\mathrm{CH}_{2}-\mathrm{O}$ (60.56) ppm shift to 61.44 ppm [22]. 
Table (3)

Characteristic infrared data of HSL and metal complexes.

\begin{tabular}{|c|c|c|c|c|c|c|}
\hline compound & $\begin{array}{c}\mathrm{vO}-\mathrm{H}, \\
\mathrm{cm}^{-1}\end{array}$ & $\begin{array}{c}v C=N, \\
\mathrm{~cm}^{-1}\end{array}$ & $\begin{array}{c}v C-O-C, \\
\mathrm{~cm}^{-1}\end{array}$ & $\begin{array}{c}v C=C, \\
\mathrm{~cm}^{-1}\end{array}$ & $\begin{array}{c}v M-O, \\
\mathrm{~cm}^{-1}\end{array}$ & $\begin{array}{c}v M-N, \\
\mathrm{~cm}^{-1}\end{array}$ \\
\hline HSL & 3500 & 1636 & 1210 & $\begin{array}{l}1590- \\
1543\end{array}$ & - & - \\
\hline CrHSL & - & 1610 & 1150 & $\begin{array}{l}1533- \\
1518\end{array}$ & 460 & 525 \\
\hline FeHSL & - & 1632 & 1120 & $\begin{array}{l}1515- \\
1466\end{array}$ & 488 & 569 \\
\hline CoHSL & - & 1600 & 1151 & $\begin{array}{l}1589- \\
1530\end{array}$ & 489 & 537 \\
\hline
\end{tabular}

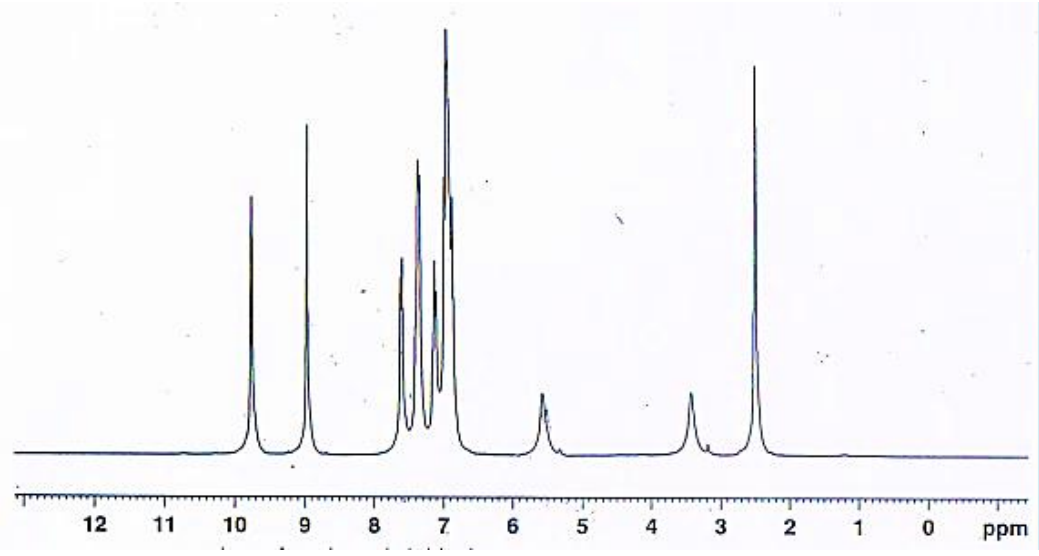

Fig. (1): ${ }^{1} \mathrm{H}$ NMR for HSL.

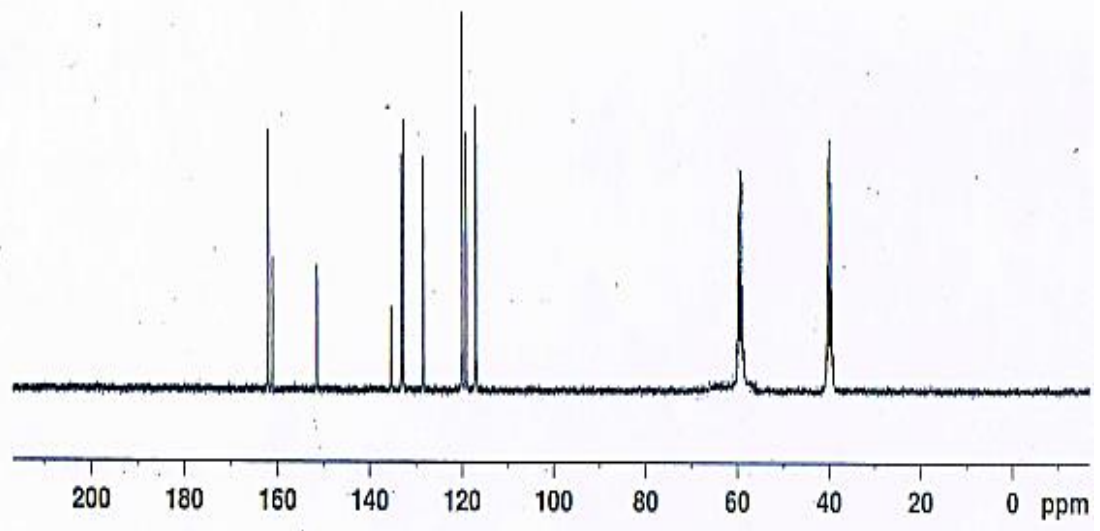

Fig.(2): ${ }^{13}$ C NMR for HSL.

3.3.Ultraviolet-Visible spectroscopy and magnetic susceptibility:

Schiff base spectrum showed two bands at $(280,399) \mathrm{nm}$. First electronic transition was for $\pi \rightarrow \pi^{*}$ and the second for $n \rightarrow \pi^{*}$ transition. Absorption bands were appeared at $582 \mathrm{~nm}$ ${ }^{4} \mathrm{~A}_{2} \mathrm{~g}(\mathrm{~F}) \rightarrow{ }^{4} \mathrm{~T}_{2} \mathrm{~g}(\mathrm{~F})\left(v_{1}\right), 430 \mathrm{~nm}{ }^{4} \mathrm{~A}_{2} \mathrm{~g}(\mathrm{~F}) \rightarrow$ ${ }^{4} \mathrm{~T}_{1} \mathrm{~g}(\mathrm{~F})\left(\mathrm{v}_{2}\right)$ and $358 \mathrm{~nm} \mathrm{n} \rightarrow \pi^{*}(\mathrm{P})\left(\mathrm{v}_{3}\right)$ for octahedral CrHSL geometry, the magnetic moment of $\mathrm{Cr}\left(\mathrm{d}^{3}\right)$ 3.7 B.M. The pale color of $\mathrm{Fe}^{3+}\left(\mathrm{d}^{5}\right)$ configuration reflecting a weak spin forbidden bands depend on the ground term ${ }^{2} \mathrm{~T}_{2} \mathrm{~g}\left(\mathrm{t}_{2 \mathrm{~g}}^{5}\right)$, the moment is around 2.2 B.M. as expected for the low spin octahedral geometry. Spin allowed d-d transitios for $\mathrm{Co}^{3+}$, two bands in the 620-422 $\mathrm{nm}$ regions attributed to ${ }^{1} \mathrm{~A}_{1} \mathrm{~g} \rightarrow{ }^{1} \mathrm{~T}_{1} \mathrm{~g}\left(\mathrm{v}_{1}\right),{ }^{1} \mathrm{~A}_{1} \mathrm{~g} \rightarrow{ }^{1} \mathrm{~T}_{2} \mathrm{~g}\left(\mathrm{v}_{2}\right)$ and the other band at $350 \mathrm{~nm}$ for $\mathrm{n} \rightarrow \pi^{*}$ transition, the 
value of moment is 5.6 B.M. for $\mathrm{Co}^{3+}$ indicating a low spin octahedral structure[18], these all data suggest the structure of complexes shown in Fig.(3).

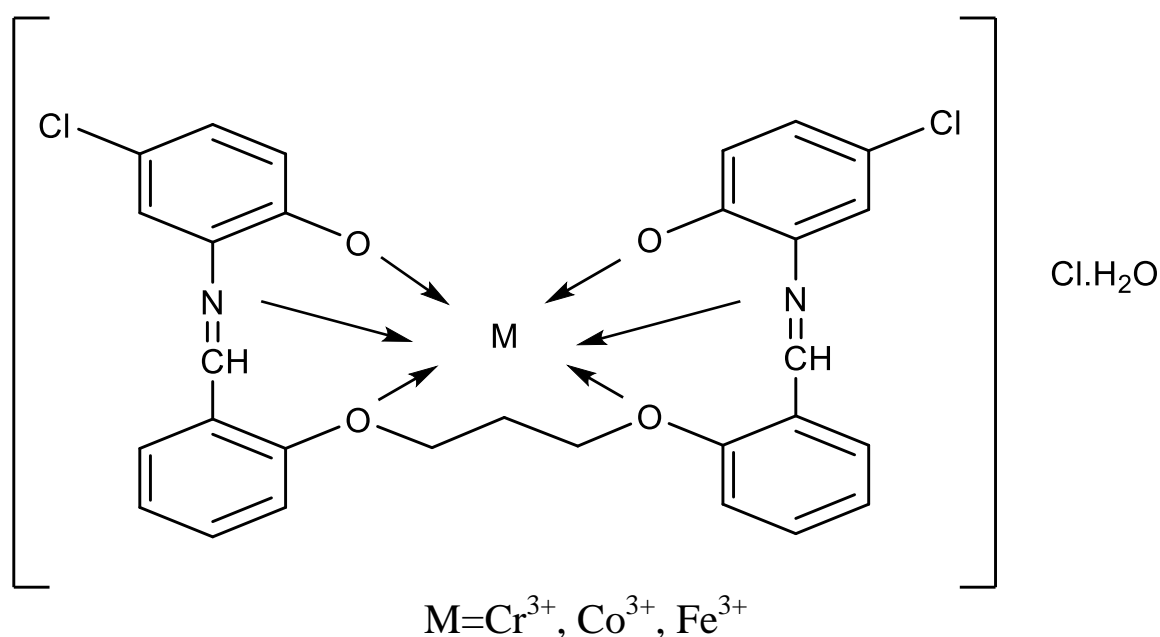

Fig.(3): Suggest conformation of HSL complexes.

\section{Biological importance of HSL complexes}

Metal complexes of hexadentate Schiff base showed a good antibacterial activity against Staphylococcus aureus and Pseudomonas aeruginosa was measured by the disc diffusion technique. The HSL and complexes were dissolved in DMSO control standard (concentrations of $50 \mu \mathrm{g} / 0.01 \mathrm{~cm}^{3}$ ). Filter paper was put in the solution of compounds in DMSO, after drying it was placed in nutrient agar plates. After $48 \mathrm{~h}$ inhibition area was observed at $37^{\circ} \mathrm{C}$, inhibition zone were measured in diameter ( $\mathrm{mm}$ )for HSL $(10,7) \mathrm{mm}$ and the complexes CrHSL $(23,29) \mathrm{mm}$, FeHSL(20,22), CoHSL $(29,20) \quad \mathrm{mm}$ for Staphylococcus aureus and Pseudomonas aeruginosa, respectively.

\section{Conclusion}

$\mathrm{Cr}$, Fe, Co trivalent ions with polyether hexadentate ligand are suggested to be octahedral complexes through $\mathrm{N}_{2} \mathrm{O}_{4}$ donor atoms. Anti-bacterial activity of HSL and their metal complexes were measured and gave good results.

\section{References}

[1] Shana B., Alireza B., "Synthesis of New Macrocycles of Ortho-Methoxy Salicylaldehyde using Claisen-Schmidt Condensation, Global Journal of Science
Frontier Research B”, Chemistry, 14 (7),3942, 2014.

[2] Ahmed M., Ibrahim M.A., "A review on versatile applications of transition metal complexes incorporating Schiff bases", J. Basic Appl. Sci., 4(2), 119-133, 2015.

[3] Ravinder K., Ravikant, "Review on Synthesis and Application of Schiff base and its transition metal complexes", R JCES, 2(2), 1-4, 2014.

[4] Arulmurugan S., Helen P. K., Venkatraman B.R., "Biological activities of Schiff base and its complexes:A review", Rasayan J.Chem, 3(3), 385-410, 2010.

[5] Al Zoubi W., "Biological Activities of Schiff Bases and Their Complexes: A Review of Recent Works", IJOC, 3, 73-95, 2013.

[6] Gülsen T., Halil B., Müjgan Y. Ö., "Spectrophotometric Determination of the Acidity Dissociation Constants of Symmetric Schiff Base Derivatives", GUJSci., 27(2), 771-783, 2014.

[7] Emad Y., Al-miery A.A., Abdulhadi K., Abdul Amir H.K., Abu Bakar M., "Photostablizing Efficiency of PVC in the presence of Schiff Base as Photostabilizer", Molecules, 20, 19886-19899, 2015.

[8] Gassan Q.A., Gamal A., Ivan H., Raghad H., Alaa J., Emad Y., "Photostability and Performance of Polystyrene Films Containing 1,2,4-Triazole-3-thiol Ring 
System Schiff Bases", Molecules, 21, 1699, 2016

[9] Bhake A.B., Shastri S.S., Limaye N.M., "A Review on Macrocyclic Complexes", Chem. Sci. Rev. Lett., 2(6), 449-455, 2014.

[10] Victor B.' Edgar V., Rolando L., Herbert H., Hiram I. B., Luis S. Z-R, "Structural and conformational analysis of neutral dinuclear diorganotin (IV) complexes derived from hexadentate Schiff base ligands", J. Org. Chem., 692(4), 731-739, 2007.

[11] Marina G.L., Carlos P. I., Fernando A., Carlos F. G., Daniel I., Jean-Claude G. B., Andres de B., Teresa R.-B., "A Schiff-Base Bibracchial Lariat Ether Forming a Cryptand-like Cavity for Lanthanide Ions", Inorg. Chem., 42(21), 6946-6954, 2003.

[12] Nura S., Hapipah M. A., Hamid Kh., Mahmood A., A. Hamid, Thong K.L., Chai L. Ch., Cher L. O., "Antibacterial evaluation of some Schiff bases derived from 2-acetylpyridine and their metal complexes", Molecules, 17, 5952-5971, 2012.

[13] Shehadeh M., Rana K., Deeb M., "Synthesis of New Azacrown Ether SchiffBases and their Complexes with $\mathrm{C}_{60}$ ", JJC, 8 (2), 71-78, 2013.

[14] Mostafa M. H. Kh., Eman H. I., Gehad G. M., Ehab M. Z., Ahmed B., "Synthesis and characterization of a novel schiff base metal complexes and their application in determination of iron in different types of natural water", OJIC, 2, 13-21, 2012.

[15] Saikat S., Kamalendu D., "Synthesis and spectroscopic characterization of some transition metal complexes of a new hexadentate $\mathrm{N}_{2} \mathrm{~S}_{2} \mathrm{O}_{2}$ Schiff base ligand", Spectrochimica Acta Part A, 62, 383-393, 2005.

[16] Jyothi S., Rao G. R., Shashank K., Sridhar K., Reddy A., Someshwar P., Swamy S.J., "Preparation and structural investigations of new hexadentate Schiff base ligands and their bivalent metal complexes, and, catalytic applications of the complexes in allylic and benzylic $\mathrm{C}-\mathrm{H}$ bond activation", Indian J Chem., 53A, 535-544, 2014.

[17] Mantha T.; Konstantina S., Christos P., Yang L., Woollins J.D., John C. P.,
"Interactions of Trivalent Lanthanide Cations with a New Hexadentate Di-Schiff Base: New Lanthanide(III) Complexes from (NE,NE)-2,2-(ethane-1,2diylbis(oxy))bis(N-(pyridin-2-ylmethylene) ethanamine)", Bioinorganic Chemistry and Applications, 2010, 1-7, 2010.

[18] Mishtu D., Jugun P. Ch., Gary J. L., Chebrolu P. R., "Synthesis and characterization of complexes of $\mathrm{Fe}$ (III), $\mathrm{Co}(\mathrm{III}), \mathrm{Ni}(\mathrm{II}), \mathrm{Cu}(\mathrm{II}), \mathrm{Zn}(\mathrm{II})$ and $\mathrm{UO}_{2}{ }^{2+}$ with p-tert-butylcalix[4]arene bearing two imine pendants linked through salicylyl moiety at the lower rim", Indian J. of Chem., 48A, 1484-1491, 2009.

[19] İsmet K.' Mustafa Y., Sermet K., "The synthesis and characterization of new oligo(polyether)s with Schiff base type", Synth. Met., 128 (3), 267-272, 2002.

[20] Rasha S. J., Farah M. I., "Synthesis and Characterization of Tetradentate Bissalicylaldehyde Schiff Base with Some Transition Metal Complexes"; J KU, 1, 124-131, 2012.

[21] Ehab M. Z., Eman H. I., Gehad G. M., Mostafa M. H., Ahmed B. K., "Synthesis, spectroscopic and structural characterization, and antimicrobial studies of metal complexes of a new hexadentate Schiff base ligand. Spectrophotometric determination of $\mathrm{Fe}$ (III) in water samples using a recovery test", Monatsh Chem, 145, 755-765, 2014.

[22] Zeliha H., Mustafa H., Hakan D., "Synthesis and Spectroscopic Characterization of New Schiff Bases Containing the Benzo-15-Crown-5 Moiety", Molecules, 9, 860-866, 2004. 